\title{
Volcanic Risk Perception, Locus of Control, Stress and Coping Responses of People Living Near the Popocatépetl Volcano in Mexico
}

\author{
Esperanza López-Vázquez \\ Psychology Faculty, Universidad Autónoma del Estado de Morelos. \\ Cuernavaca, Morelos, 62209, México \\ E-mail:esperanzal@uaem.mx \\ www.uaem.mx \\ Maria Luisa Marván \\ Institute of Psychological Research, Universidad Veracruzana. México \\ Xalapa, Veracruz City, 9110, México. \\ E-mail:mlmarvan@gmail.com \\ www.uv.mx \\ Received 18 February 2012 \\ Accepted 12 March 2012
}

\begin{abstract}
The influence of locus of control and stress on coping strategies in relation to volcanic risk were studied in 156 people living near the Popocatépetl volcano in Mexico. The participants with a limited educational background were more likely than those with higher education to use passive coping strategies. Linear regression showed that a higher level of psychological stress predicts more active strategies. These results confirm some of our previous studies. Probable explanations for our findings are discussed.
\end{abstract}

Keywords: Locus of control, Stress, Coping strategies, Volcanic risk

\section{Introduction}

There are numerous volcanoes in the world that are active, and around 50 or 60 volcanoes erupt annually ${ }^{1}$. Even though volcanic threats have always existed and have brought disaster to afflicted populations, research on the social impact of such risks did not develop until well into the 20 Century. Since the 1990s, a larger number of works have shown the link between risk perception and people's behavior in a volcanic risk environment $2,3,4,5$. Natural hazards have been frequently analyzed as being part of the social relationship of production ${ }^{6,7}$. Some topics developed in these studies are: the perception of risk and peoples' behaviors in a volcanic risk scenario and/or the influence of religious beliefs $8,9,10,11$; peoples' responses to volcanic risks ${ }^{12,13,14}$; the impact and efficiency of risk communication for people exposed to risk $^{15,16,17}$; risk perception and socioeconomic variables $18,15,10$; risk perception, knowledge and preparedness ${ }^{19}$, 13, 20, 21; risk perception and risk management ${ }^{22}$; and culture and volcanic risk mitigation ${ }^{23,24}$.

Volcanic risk ${ }^{*}$ and volcanic risk perception are a main topics of interest in México due to the many volcanoes currently active in the country. There are 16 active volcanoes $^{25}$. The majority of the volcanoes are located in the center of the country where there are at least 36 million people exposed to the risk. The Popocatépetl volcano is one of the most active, with a high risk level

\footnotetext{
${ }^{\text {a }}$ Volcanic risk can be understood as the likelihood of a person or a property to be injured/killed or damaged by a volcanic hazard. It depends on the timescale, the location of the person/property and the current state of the volcano

(http://www.volcanodiscovery.com/volcanic_risk.html).
} 
and intermittent periods of activity. The current period of volcanic activity began in December 1994, presenting intense seismic activity, followed by explosions. Ash falls have been the principal problem arising from the recent activity. The hazards surrounding Popocatépetl have been divided into three risk zones according to proximity to the source. These zones are classified on a volcanic hazard map for pyroclastic flows (composed of blends of solid or liquefied particles and gases at very high temperature that may act as a liquid with high mobility and destructive power), tephra falls (different volcanic materials such as pumice stone with very little pyroclastic elements), landslides (movements of the land provoked by the activity of a volcano), and lahars (flows containing volcanic stone fragments that may incorporate water and mud when descending the volcano's slopes) ${ }^{26}$. The divisions are determined by the distance from the crater and by the risk intensity of each zone ${ }^{27}$.

It is important to clarify that "risk" is a concept than can be defined from two perspectives: 1) the objective evaluation that define risk as a function of the interaction between the harmful effects of a hazard and the vulnerability of individuals to these effects ${ }^{21,28} ; 2$ ) and the subjective evaluation that involves the cognitive analysis that each individual make of a hazard that is constructed along its own life ${ }^{28}$. Thus, risk perception, defined from the psychosocial point of view, is understood as a process that is influenced by different factors that are personal, social, political, historical and cultural ${ }^{30}$. The perception of a risk also depend on specific factors such as familiarity with the hazard, the voluntary acceptance of the activity, the degree of the exposure one is submitted to, the knowledge one has of said hazard, the degree of control one has to avoid or mitigate the effects that said hazard has, the novel or chronic nature of the hazard, the fear that is generated by the constant exposition to the risk situation, and the actual real severity of the threat ${ }^{31,32}$; the social benefit that the hazard offers, the acceptability people express regarding said hazard, and the trust people have in the regulatory and official bodies in charge $\mathrm{e}^{33,34,35,36,37}$, and other factors that make exposure to volcanic risk a complex process to study.

The perception of risk, when added to a threat that may disrupt people's stability, generates tension in a person's life. This tension has been called "stress", and is provoked by exterior stimuli that threaten the organism and generate the organic response we call stress ${ }^{38}$. In his studies on the subject, Lazarus concludes that a certain stimulus is capable of generating stress only if it is evaluated (cognitive process) by the subject as being stressful $^{39,40,41}$. Considering that a hazard, which represents a potential threat, can generate the stress response; this process is strongly related to other variables such as personality, experience with the hazard, the knowledge one has of the hazard ${ }^{42}$ and the educational, socio-economic levels of individuals, ${ }^{39}$ and subjective evaluations. Behaviors that are generated by confronting a stressful stimulus are called coping strategies, and are designed to defend and protect the individual from the stressor that is evaluated as threatening ${ }^{43}, 44$. These strategies can be classified in different ways, but in this paper they will be separated into two large groups: active and passive coping strategies. The first group corresponds to all those active behaviors that directly confront a threat (such as gathering information, direct evasive actions, or attempts to control or mitigate the situation); the second group refers to behaviors characterized by rejection or denial of the event, withdrawal, or passive acceptance ${ }^{45}$. Taking into account Lazarus's model of stress, Duval and Mulilis have proposed the Person Relative Event (PrE) Model. This model says that that increasing levels of threat, when resources of an individual are appraised as sufficient relative to the magnitude of the threat, will increase problem-focused coping, (in other words, the active coping). On the contrary, increasing levels of threat when resources are appraised as unsatisfactory relative to threat scale will decrease problem-focused coping (PFC) $)^{46,47,48,49}$. According to the authors and studies using this PrE model, theory is related to locus of control, which refers to generalized beliefs about the causes of people's outcomes ${ }^{50,51}$.

The concept of locus of control refers to the individual's perception of his or her own capability to control a given situation, and which in turn depends on certain reinforcing events that allow the person to test the level of control that he or she feels towards the given object, person or event. Through such relationships, individuals may recognize the existence of certain situations they themselves can control or mitigate by their own intervention (internal control), or that may be controlled or mitigated by external forces or other persons 
(external control) ${ }^{51,52,53,54}$. In the case of natural hazards, it has been found that people with an internal locus of control believe that life events may be at least partially controlled by their own actions, they are well prepared for tornadoes ${ }^{55}$, they also buy more flood insurance $^{56}$, and see earthquake possible damages as more preventable than do people with an external locus ${ }^{57}$. Locus of control also predicts mitigation actions more than survival actions ${ }^{58}$.

\section{Overview}

Many studies have been carried out examining the perception of volcanic risk in different contexts and different populations around the world, but little has been done to evaluate the level of stress produced by such exposure to risk or the types of coping strategies that people use. A previous study on people living in different volcanic risk zones around the volcano Popocatépetl showed that one factor of the perception of risk is the feeling of insecurity linked to the volcanic risk, and that this factor influences the level of stress in people who live around the volcano. In that study, when interaction effects between risk zones and the other variables were analyzed, it was found that active coping strategies were moderated according to risk zone. Results also demonstrated that risk zone operates as a moderating variable, acting with coping strategies to determine stress levels ${ }^{14}$.

The goals of this study were: a) To study the level of stress, the type of locus of control (internal-external), and the type of coping strategies (active-passive) used by people living near a volcanic risk area, according to their education level; b) To study the influence of locus of control and stress on coping strategies in relation to volcanic risk. We expect that people with a higher education use more active and less passive coping strategies, and show a more internal locus of control than people with lower education level, and more stress. Furthermore, we expect that both locus of control and stress have influence on coping strategies used by participants.

\section{Method}

\subsection{Participants}

The sample was composed of 156 adults between the ages of 18 and 60 . All of them were residents of the cities of San Pedro Cholula or Cuautla, in Mexico. Both cities are located at $20 \mathrm{~km}$ from the Popocatépetl volcano crater. To make sure that participants had lived a considerable time under the volcanic risk, an inclusion criterion was that participants had to have lived in the risk zone for at least five years.

The participants were divided into two groups according to their educational level:

a) People with a limited educational background (37 women and 36 men), whose schooling varied from six to nine years. They were blue-collar workers and had jobs that are usually poorly paid. Women who did not work were housewives married to blue-collar workers. In accordance with the limited educational level of these participants as well as the nature of their employment, we inferred they held a lower or lower-middle socioeconomic status.

b) People with higher education, whose schooling was at least 12 years (51 women and 32 men). These participants were white-collar workers and held positions that are usually well paid. Women who did not work were housewives whose husbands were whitecollar workers. In Mexico, people with higher education earn, on average, 300\% more than those who did not complete their basic education $^{53}$. Thus, we inferred that these participants had an upper-middle socioeconomic status.

\section{Characteristics of the Visited Cities}

In 2005, the population of the city of San Pedro Cholula was well over 110,000 inhabitants. Most frequent occupations include agriculture (corn, beans, alfalfa, and certain species of flowers); stockbreeding (goats, cows, pigs and sheep); industry (mainly fabrication of bricks and tiles for construction and decorative use); as well as commerce, government officials, teachers, technicians and blue-collar labor ${ }^{59}$. The municipality is well known both nationally and internationally due to its historical importance during the pre-Hispanic period of Mexican history. It was a very important ceremonial center.

The city of Cuautla had more than 150,000 inhabitants in 2005 and notable occupations included agriculture (beans, onions, rice, cucumber, green tomatoes, zucchini and sugar cane), stockbreeding, poultry farming, beekeeping, aquaculture, agro-industry, commerce and tourism ${ }^{60}$. 
It is important to point out that both cities are located in risk zones which, in the event of a volcanic eruption, would be exposed to pyroclastic flows, lahars, and ash fall ${ }^{25}$.

\subsection{Instruments}

In the first part of the survey participants completed a basic information sheet that asked general questions in order to know how many years had they lived in that city, and other socio-economic data. After that, participants answered three different questionnaires: a) Coping strategies scale (CSS). This scale was adapted from the "Echelle Toulousaine de Coping"45 and validated in Mexico by López-Vázquez and Marván ${ }^{61}$. This instrument is a 5-point Likert scale from 1- "I never react that way" to 5- "I always react that way". The questionnaire has 26 items that measure two factors: 1) Active coping strategies, which includes items that refer to direct active behaviors relating to the problem, searching for information, strategies that anticipate the problem, as well as self-control and control of circumstances; and 2) Passive coping strategies which includes items that refer to behaviors such as rejection or denial of the event, withdrawal or passive acceptance. Participants were asked to respond to this scale according to their experience of the Popocatépetl volcanic risk. The questionnaire's reliability was .86 using Chronbach's alpha coefficient.

b) Stress scale (SS). This scale was adapted and validated in Mexico by Jiménez ${ }^{62}$ from the "Echelle Toulousaine de Stress"45. It is composed of 27 items that examine typical reactions that most people present when they are exposed to a stressful event. The first factor in this scale is psychological stress, which refers to different feelings such as threatened, helpless, lonely, lack of control or lack of understanding about the stressful situation. The second factor concerns the psychophysical exhaustion stress, which refers to the presence of physical manifestations such as having a knot in one's throat or being exhausted most of the time. The third factor is psycho-physiological stress, which refers to feeling tired, being unable to sleep or becoming agitated. Finally, the fourth factor is physiological stress, which refers to physiological reactions caused by stress as having stifling heat or accelerated heart beat. This instrument is a 5-point Likert scale from 1- "I never react that way" to 5- "I always react that way". The participants were asked to answer according to the stress they felt related to the volcano Popocatépetl (Chronbach's alpha $=.94$ ).

The coping and stress scales were chosen because they were written in a general sense that can be adapted to any stressing event. The instructions allow to the researcher to specify clearly the situation we are studying, and for our study, the items were adapted to volcanic risk.

c) Locus of control scale (LCS). This scale was developed in Mexico by La Rosa ${ }^{53}$. The original scale has 61 items, but we used 48 items that loaded onto five subscales: The first subscale, "instrumental internality," refers to situations that individuals are able to control in accordance with their personal capabilities. The second subscale is the "affective scale" and describes objectives reached by affective relationships between people. The third factor, "fatalism/luck," consists in reliance on fortune or faith to face different situations (external factor). The fourth factor, called "microcosm powerful," refers to people that are close to an individual (family or friends) having some power over that person's life (external factor). The fifth factor, called "macrocosm powerful," describes people that are more distant from an individual (frequently they have never talk to them as religious guides or politicians) having an influence on them (external factor). This scale was scored in a Likert 5-points scale from 1"Completely disagree", to 5- "Completely agree"(Chrombach’s alpha = .78).

\subsection{Procedure}

The survey method was employed in this research. This method allows recruiting participants in their natural environment. An interviewer visited both cities over a period of about two months. During these visits, adults were approached in their workplaces, on the streets or in stores and were asked if they would be willing to participate in a study regarding the Popocatépetl volcano. After ascertaining that individuals fulfilled the criteria mentioned, interviewer set up a time and a place to meet with the participant in order to conduct the survey. People were polled individually. The interviewer gave the questionnaires to the participants and made sure that they understood the meaning of the 
items. If the person understood, the interviewer let him/her complete the questionnaire independently; if not, the interviewer read each of the items in the surveys to make sure that the participants properly understood each question and recorded their answers.

Each individual survey took from 20- 30 minutes to complete.

\subsection{Data analyses:}

Data analyses were performed using the statistical package SPSS Version 16.0. Independent sample T-tests were conducted to compare the locus of control, the stress level and the coping strategies of participants depending on their educational level. Linear regressions were performed with the coping strategies scores as dependent variables, and the independent variables were: years of schooling, the five factors comprised in the locus of control scale, and the four factors comprised in the stress scale.

\section{Results}

The results of both groups of participants according of their educational level are shown in Table 1 . The participants with limited educational backgrounds were more likely than those with higher education to use passive coping strategies. However, there are no significant differences when comparing active strategies.

Table 1. Means (M) and Standard deviation (SD) for Coping Strategies, Locus of Control, and Stress for participants with limited educational backgrounds $(\mathrm{n}=73)$ and with higher levels of education $(n=83)$

\begin{tabular}{lllll}
\hline & $\begin{array}{l}\text { Limited } \\
\text { education }\end{array}$ & & $\begin{array}{l}\text { Higher } \\
\text { education }\end{array}$ & \\
& $M \quad(S D)$ & & $M \quad(S D)$ & $\begin{array}{l}\text { Student } \\
\text { t test }\end{array}$ \\
\hline $\begin{array}{l}\text { coping - active } \\
\text { strategies }\end{array}$ & $\begin{array}{l}3.15 \\
(0.77)\end{array}$ & & $2.90(0.84)$ & 1.90 \\
$\begin{array}{l}\text { coping - passive } \\
\text { strategies }\end{array}$ & $\begin{array}{l}2.99 \\
(0.76)\end{array}$ & & $2.71(0.65)$ & $2.46 * *$ \\
stress - exhausting & $\begin{array}{l}1.89 \\
(0.73)\end{array}$ & $1.93(0.73)$ & 0.31 \\
& & &
\end{tabular}

\begin{tabular}{|c|c|c|c|}
\hline stress - physical & $\begin{array}{l}1.70 \\
(0.66)\end{array}$ & $1.79(0.83)$ & 0.70 \\
\hline $\begin{array}{l}\text { stress } \\
\text { psychophysical }\end{array}$ & $\begin{array}{l}1.94 \\
(0.71)\end{array}$ & $1.81(0.64)$ & 1.24 \\
\hline $\begin{array}{l}\text { stress } \\
\text { psychological }\end{array}$ & $\begin{array}{l}2.23 \\
(0.78)\end{array}$ & $2.12(0.76)$ & 0.87 \\
\hline l.c. - affective scale & $\begin{array}{l}3.23 \\
(0.98)\end{array}$ & $3.20(0.95)$ & 0.19 \\
\hline $\begin{array}{l}\text { l.c. - instrumental } \\
\text { internality }\end{array}$ & $\begin{array}{l}1.67 \\
(0.51)\end{array}$ & $1.86(0.61)$ & $2.14 *$ \\
\hline $\begin{array}{l}\text { l.c. - macrocosm } \\
\text { powerful }\end{array}$ & $\begin{array}{l}3.04 \\
(0.83)\end{array}$ & $3.01(0.77)$ & 0.21 \\
\hline $\begin{array}{l}\text { l.c. - microcosm } \\
\text { powerful }\end{array}$ & $\begin{array}{l}2.56 \\
(0.90)\end{array}$ & $2.53(0.72)$ & 0.24 \\
\hline l.c. - fatalism/luck & $\begin{array}{l}2.73 \\
(1.12)\end{array}$ & $2.32(0.91)$ & $2.54 * *$ \\
\hline
\end{tabular}

l.c. = locus of control

${ }^{*}$ p value $<.05, * *$ p value $<.01$

Concerning locus of control, there were significant differences in two subscales of the LCS: Participants with higher education scored higher than those with limited educational background on the "instrumental internality" subscale and they scored lower on the "fatalism/luck" subscale.

There were no significant differences when any of the stress subscales were compared between both groups of participants.

In order to identify some of the possible variables that influence coping strategies related to volcanic risk, two linear regression analyses were conducted. In the first one the score of the passive coping strategy was entered as dependent variable, and in the second the score of the active coping strategy was the dependent variable. Both models were statistically significant. As can be seen in Table 2, we found that passive coping strategies were predicted by: (a) higher scores on the "fatalism/luck" subscale of the locus of control scale; (b) higher scores on the "psycho-physical exhaustion" subscale of the stress scale; and (c) lower schooling. Additionally, we found that active coping strategies were predicted by 
both higher scores on the "psychological stress" subscale of the stress scale and lower scores on the “"macrocosm powerful" subscale of the locus of control scale.

Table 2. Hierarchical Regression Analysis for Variables Predicting Coping Strategies.

Coping strategies

Passive strategies Active strategies

\begin{tabular}{|c|c|c|c|c|c|c|}
\hline \multirow[b]{3}{*}{ Variables } & \multicolumn{3}{|c|}{ Passive strategies } & \multicolumn{3}{|c|}{ Active strategies } \\
\hline & & $S E$ & & & $S E$ & \\
\hline & $B$ & $B$ & Beta & $B$ & $B$ & Beta \\
\hline Schooling & -.08 & .04 & $-.13^{*}$ & -.08 & .06 & -.10 \\
\hline $\begin{array}{l}\text { l.c. - affective } \\
\text { scale }\end{array}$ & -.14 & .07 & $-.19 *$ & .02 & .10 & .03 \\
\hline $\begin{array}{l}\text { l.c. } \\
\text { instrumental } \\
\text { internality }\end{array}$ & -.03 & .08 & -.02 & -.15 & .12 & -.11 \\
\hline $\begin{array}{l}\text { l.c. } \\
\text { macrocosm } \\
\text { powerful }\end{array}$ & -.07 & .07 & -.08 & -.27 & .10 & $-.27 * *$ \\
\hline $\begin{array}{l}\text { l.c. } \\
\text { microcosm } \\
\text { powerful }\end{array}$ & -.08 & .08 & -.09 & .05 & .12 & .05 \\
\hline $\begin{array}{l}\text { l.c. } \\
\text { fatalism/luck }\end{array}$ & -.29 & .06 & $.42 * *$ & .03 & .08 & .04 \\
\hline $\begin{array}{l}\text { stress } \\
\text { exhausting }\end{array}$ & -.21 & .10 & $.22 *$ & -.17 & .15 & -.15 \\
\hline $\begin{array}{l}\text { stress } \\
\text { physical }\end{array}$ & -.02 & .10 & .02 & -.04 & .14 & -.04 \\
\hline $\begin{array}{l}\text { stress } \\
\text { psychophysical }\end{array}$ & -.05 & .11 & -.05 & .15 & .16 & .12 \\
\hline $\begin{array}{l}\text { stress } \\
\text { psychological }\end{array}$ & .14 & .10 & .15 & .38 & .15 & $.36 * *$ \\
\hline
\end{tabular}

* $\mathrm{p}<.05 ; * * \mathrm{p}<.01$

According to the variance inflation factor (VIF) test, there were no co-linearity problems in our data since all VIF scores were lower than three.

\section{Discussion}

The results obtained in the present study show that some subscales of the variables studied have a clear influence on the coping strategies used by participants. We observed that the control locus "fatalism/luck" factor tends to predict the use of passive strategies. This makes sense if we consider that, according to the authors of the locus of control scale, people who tend to control externally feel less able to handle environmental problems than those who do so internally ${ }^{55}$, and such individuals also have a tendency to believe that control of the situation lies beyond their ability. According to the PrE model, under conditions in which resources are appraised by individuals as insufficient relative to threat, increasing absolute levels of appraised menace will decrease the Problem Focused Coping (PFC), independently of the level of appraised resources ${ }^{58}$. In that case, more passive coping strategies are able be used by people. Moreover, according to Mulilis and Duval ${ }^{48,49}$, this predicted effect is more evident under conditions of high personal responsibility for preparation, as opposed to low levels of the same variable, and so, it has less active implications as it might happened in our present study.

These results could be also explained taking into account the socio-cultural aspects of the Mexican tendency to favor passive behaviors and to promote disengagement from social problems. Díaz-Guerrero, in his studies on the "Psychology of the Mexican", describes how the most effective strategy that the Mexican has to face stress in life is to do so passively, due to the social assumption that passivity is a sign of "virtuosity". This is promoted by the influence of the Catholic religion, which favors the tendency to accept one's fate without qualms ${ }^{63}$.

Other variables that predicted the use of passive strategies were low educational level and psychological exhaustion. In this regard, a study analyzing risk perception of precollege students for 20 environmental hazards, and its relationship to gender, community socioeconomic setting (CSES), age, and locus of 
control, found that lower CSES students had less internal control locus than higher CSES students, and the authors confirmed that these relationships are generally consistent with previous research ${ }^{64}$. Another study conducted in Sonora, Mexico, on risk perception and behavior towards protecting the environment, showed that people from lower economic levels, and those of a more advanced age, perceive greater social and personal risk from environmental hazards, which, according to the authors, might reflect a greater state of defenselessness due to their lower economic resources ${ }^{65}$. As mentioned earlier, Lazarus ${ }^{39}$ has shown how personal resources and variables such as demands, limitations or opportunities, as well as other variables that include intelligence, social abilities, recent friendships, physical health, and of course education and money, may influence an individual's stress response. This suggests that both the level of stress a person develops, and the type of response he or she makes to a stressing situation will be in accordance with his/her available resources. If the individual lacks available resources that he or she considers necessary, no adaptation or strategy will permit him or her to satisfy the external demand. This is when the stress response is stifled by the impossibility to act and may in the long run negatively affect the individual's health ${ }^{66}$, 39, 44 .

Another of our findings demonstrated that higher levels of psychological stress predict more active coping strategies. Thus, the stress generated by exposure to volcanic risk tends to stimulate actions by the individual rather than reducing or annulling them. In a previous study carried out in a population near Popocatépetl, the researchers looked for a relationship between feelings of insecurity and stress and coping strategies. This study showed that people using more active coping strategies reported experiencing more stress. In that study, the authors concluded that the stress and concomitant risk caused by volcanic activity probably had the role of a positive stress ${ }^{14}$, or maybe in the sense of Lazarus, a challenge $^{40}$. We consider that our finding is directly related with the individual's evaluation of the stressful situation and his/her determination of whether it can be controlled, depending on perceived resources and other factors that tend to reduce anxiety. Some of these factors related to the perception of risk may include: (a) familiarity with the hazard from daily exposure to it, (b) specific knowledge people have concerning the risk, (c) peoples' toleration of, or willingness to be exposed to, volcanic risks, (d) the control people may feel they have because volcanic risk may not be a daily source of stress in their lives, and (e) the extent of knowledge that people may have concerning the dangers and possible preventive measures that may be available to them ${ }^{31,67}$. Considering the PrE model, the resources of our participants are certainly assessed as sufficient to face the threat, and we can interpret that these people are using $\mathrm{PFC}^{46,47,48,49}$. This kind of coping allows people to be centered in preparedness actions to face natural hazards. It is important to state that after the 1994 eruptions, the government informed people by TV, radio, newspaper, internet, and printed announcements in bus stops and highways stands, which stated the actions the population should carry out in case of a volcanic eruption. Some of these instructions included having important papers at hand, storing reserves of water and food, protecting windows and entries from ash falls, taking out ash from weak building structures. Other actions were carried out by the University Center for the Prevention of Disasters (Centro Universitario de Prevensión de Desastres - CUPREDER) and by the government through a program called the Popocatépetl $\operatorname{Plan}^{68}$. Public awareness campaigns were carried out to inform populations dwelling near the Popocatépetl, concerning the principal preventive measures to be taken. Such activities may foster more positive feelings of control over the situation in case the threat of volcanic activity becomes imminent.

Another finding of the current research is that low scores in external locus of control (those that are powerful in the macrocosm) also predict active coping strategies. This corresponds to the locus of control theory which holds that people who use less external control will use more internal control by applying their direct coping capabilities to a greater extent ${ }^{51,52,48}$.

We also noticed that the internality factor of locus of control is relatively low in both groups. Considering the PrE model, we can think that our participants evaluate their resources as insufficient, and this could be a reason of their low internality. We cannot say more about this result because our measure was not concentrated in responding about natural hazards, it was a general scale that shapes a personality feature. 
Finally, this study could be replicated in Mexico or in other countries wherever populations are exposed to volcanic hazards in order to compare results and validate our findings. We believe it is important to continue exploring these variables and others such as cognitive bias, knowledge of preventive measures, attitudes, etc. with populations exposed to natural hazards, for the purpose of increasing our knowledge of cognitive mechanisms involved in the perception of risk and peoples' responses when faced with such hazards. Such studies can be of great use in improving our methods of communicating information about the potential risks and preventive measures to people that are exposed to these hazards.

Acknowledgments: The authors wish to thank Mónica Encinas Herrera who assisted us in the collection of data.

\section{References}

1. Simkin T. Terrestrial volcanic eruptions in space and time. Proceedings of Kagoshima International Conference on Volcanoes. Kagoshima Prefectural Government. (Kagoshima, Japan, 1988). pp. 412-415.

2. Lachman, R. \& Bonk, W. J. Behavior and beliefs during the recent volcanic eruption in Kapolo, Hawaii. Science, 131 (3407) (1960). 1095-1096.

3. Greene, M.R., Perry, R.W., Lindell, M.K. The March 1980 eruptions of Mt. St. Helens: citizen perceptions of volcano hazard. Disasters, 5 (1) (1981). 49-66.

4. Perry, R.W., Lindell, M.K. \& Greene, M.R. Threat perception and public response to volcano hazard. The Journal of Social Psychology, 116, (1982). 199-204.

5. Gaillard, J. C. Volcanic risk perception and beyond. Journal of Volcanology and Geothermal Research, 172. (2008). 163-169.

6. Odum, E. P. Fundamentals of Ecology, 3rd ed. (Philadelphia, Saunders College Publishing 1971).

7. Worster, D., The ecology of order and chaos. Environmental History Review, 14 (1/2) (1990). 1-18.

8. Dove, M. R. Perception of volcanic eruption as agent of change on Merapi volcano, Central Java. Journal of Volcanology and Geothermal Research. 172. (2008). 329337.

9. Chester, D. K., Duncan A. M., Dibben \& C. J.L. The importance of religion in shaping volcanic risk perception in Italy, with special reference to Versuvius and Etna. Journal of Volcanology and Geothermal Research. 172. (2008). 216-228.

10. Lavigne, F., De Coster B., Juvin, N., Flohic, F., Gaillard J. C., Texier, P., Morin, J. \& Sartohadi, J. People's behaviour in the face of volcanic hazards: Perspective from Japanese communities, Indonesia. Journal of Volcanology and Geothermal Research. 172. (2008). 273287.

11. Perry, R.W., Lindell, M.K. Volcanic risk percepcion and adjustment in a multi-hazard environment. Journal of Volcanology and Geothermal Research, 172. (2008). 170178.

12. Gaillard, J. C. Alternative paradigms of volcanic risk perception: The case of Mt. Pinatubo in the Philippines. Journal of Volcanology and Geothermal Research. 172. (2008). 315-328.

13. Gregg, C.E., Houghton, B.F., Paton, D., Swanson, D.A. \& Johnston, D. M. Community preparedness for lava flows from Mauna Loa and Hualalai volcanoes, Kona, Hawai’i. Bulletin of Volcanology. 66. (2004). 531-540.

14. López Vázquez, E., Marván M. L., Flores F. \& Peyrefitte A. Volcanic risk exposure, feelings of insecurity, stress and coping strategies in Mexico. Journal of Applied Social Psychology. 38(12). (2008) pp. 2885-2902.

15. Baberi, F., Davis, M.S., Isaia R., Nave, R. \& Ricci, T. Volcanic risk perception in the Vesuvis population. Journal of Volcanology and Geothermal Research. 172. (2008). 244-258.

16. Haynes, K., Barclay, J. \& Pidgeon, N. Woshe reality counts? Factors affecting the perception of volcanic risk. Journal of Volcanology and Geothermal Research. 172. (2008). 259-272.

17. Solana, M.C., Kilbum, C.R.J., \& Rolandi, G. Communicating eruption and hazard forecasts on Versuvius, Southern Italy. Journal of Volcanology and Geothermal Research. 172. (2008). 308-314.

18. Dibben, C. J. L. Leaving the city for the suburbs - The dominance ordinary decision making over volcanic risk perception in the production of volcanic risk on Mt. Etna, Sicily. Journal of Volcanology and Geothermal Research. 172. (2008). 288-299.

19. Carlino, S., Somma R. \& Mayberry G.C. Volcanic risk perception in the Vesuvius population. Journal of Volcanology and Geothermal Research. 172. (2008). 229243.

20. López Vázquez, E. Risk perception and coping strategies for risk from Popocatépetl Volcano, Mexico. Geofísica Internacional. 48 (1). (2009). 301-315.

21. Paton, D., Smith, L. \& Johnston, D. Volcanic hazards: risk perception and preparedness. New Zealand Journal of Psychology. 29 (2). (2000). 86-91.

22. Gavilanes-Ruíz, J. C., Cuevas-Muñiz, A., Varley, N., Gwynne, G., Stevenson, J., Saucedo-Girón, R., PérezPérez, A., Aboukhalil, M. \& Cortés-Cortés, A. Exploring the factors that influence the perception of risk: The case of Vocán de Colima, Mexico. Journal of Volcanology and Geothermal Research. 186. (2009). 238-252.

23. Gregg C.E., Houghton, B.F., Paton, D., Swanson, D.A., Lachman R. \& Bonk, W.J. Hawaiian cultural influences 
on support for lava flow hazard mitigation measures durin the January 1960 eruption of Kilauea volcano, Kapoho, Hawaii. Journal of Volcanology and Geothermal Research, 172, (2008). 300-307

24. Paton, D., Smith, L., Daly, M. \& Johnston, D. Risk perception and volcanic hazard mitigation: Individual and social perspectives. Journal of Volcanology and Geothermal Research. 172. (2008). 179-188.

25. Macías, J. L. \& Capra- Pedol, L. Los volcanes y sus amenazas. (México, Fondo de Cultura Economica. 2005).

26. De la Cruz, R. S. \& Ramos, J. E. Definición y clasificación de calamidades de origen volcánico y sus efectos. (México, CENAPRED. 1995).

27. Macías, J.L., Carrasco, G., Delgado, H., Martin Del Pozzo, A.L., Siebe, C., Hoblitt, R., Sheridan, M.F. \& Tilling, R.I. Mapa de peligros volcánicos del Popocatépetl, scale 1:25,000 (México: Universidad Nacional Autónoma de México, Instituto de Geofísica. (1995).

28. Weyman, A. K. y Clarke, D.D. The effect of familiarity on workplace risk assessment - contextual insight or cognitive availability? Contemporary Ergonomics, Publ. Taylor and Francis, (2003). 463-470.

29. Assally, J. P. Les jeunes et le risque: Une approche psychologique de l'accident. (Paris, Vigot. 1992).

30. Slovic, P. Perception of risk. In P. Slovic (Ed.), The perception of risk. (London, Earthscan Publications Ltd. 2000).

31. Slovic, P. (1987). Perception of risk. Science ,236, 28085.

32. Fischhoff, B., Slovic, P., Lichtenstein, S., Read, S. \& Combs, B. How Safe Is Safe Enough? A Psychometric Study of Attitudes Toward Technological Risks and Benefits. In P. Slovic (1 Eds.), The Perception of Risk, (80-103). (London, Earthscan Publications Ltd. 2000).

33. Bronfman, N. Perception and acceptability of Technological and Environmental Hazards in Chile, $(\mathrm{PhD}$ thesis Pontifica Universidad Católica de Chile, 2005).

34. Bronfman, N. C., López-Vázquez, E., Gutiérrez, V. V. \&Cifuentes, L. A. Trust, Acceptance and Knowledge of Technological and Environmental Hazards in Chile. Journal of Risk Research 11(6), (2008). 755-773.

35. Bronfman, N. C., López-Vázquez, E. \& Dorantes, G. An Empirical Study for the Direct and Indirect Links between Trust in Regulatory Institutions and Acceptability of Hazards. Safety Science. 47. (2009). 686-692.

36. Siegrist, M. The Influence of Trust and Perceptions of Risk and Benefits on the Acceptance of Gene Techonology. Risk Analysis 20(2). (2000). 195-203.

37. Siegrist, M., \& Cvetkovich, G. T. Perception of Hazards: The Role of Social Trust and Knowledge. Risk Analysis. 20(5). (2000). 713-719.

38. Selye, H. La Tensión de la Vida (el estress). (Argentina, Compañía General Fabril Editora. 1960).
39. Lazarus, R. S. Estrés y Emoción. Manejo e Implicaciones en Nuestra Salud. (España: Desclée De Brower. 2000).

40. Lazarus, R. S., \& Folkman, S. Stress, appraisal, and coping. (New York, Springer Pub. 1984).

41. Appley, M. H. \& Trumbull, R. Psychological Stress: issues in research. (New York: Appleton-Century-Crofts. 1967).

42. Lazarus, R. S. \& Launier, R. Stress related transactions between person and environment. Perspectives in international. (New York: Psychology New York Presses. 1978).

43. Lazarus, R. S., \& Folkman Estrés y Procesos Cognitivos. (México: Ediciones Martínez Roca. 1991).

44. Esparbès, S., Sordes-Ader, F. \& Tap, P. L'Échelle Toulousaine de coping: Un instrument pour l'analyse des liens entre personnalisation et stratégies de coping. Data report 1993. St. Cricq, (France, Journées du Labo PCS, Université de Toulouse Le-Mirail. 1993).

45. Duval, T. S., Duval. V. H., \& Mulilis, J. P. Self-focus, degree of discrepancy between self and standard, outcome expectancy favorability and behavior. Journal of Personality and Social Psychology, 62, (1992). 340-348.

46. Duval, T.S., Mulilis, J.P. A Person-Relative-to-Event (PrE) Approach to Negative Threat Appeals and Earthquake Preparedness: A field study. Journal of Applied Social Psychology 29, (1999). 495-516.

47. Mulilis, J.P., \& Duval, T. S. Negative threat appeals and earthquake preparedness: A person-relative-to-event (PrE) model of coping with threat. Journal of Applied Social Psychology, 25, (1995). 13 19- 1339.

48. Mulilis, J-P., \& Duval, T. S. The PrE model of coping and tornado preparedness: Moderating effects of responsibility. Journal of Applied Social FëSyCholOgy, 27, (1997). 1750-1766.

49. Carver, C. S. The Internal-External Scale confounds internal locus of control with expectancies of positive outcomes. Personality and Social Psychology Bulletin,23, (1997). 580-585.

50. Rotter, J. B. Generalized Expectancies for Internal Versus External Control of Reinforcement. Psychological Monographs, 80, 1-609. (1966).

51. Dubois, N. La Psychologie du Contrôle. Les croyances internes et externs. (France, Presses Universitaires de Grenoble. 1987).

52. La Rosa, J. Escalas de locus de control y autoconcepto: construcción y validación. Ph. D. Thesis in Social Psychology. (México, Universidad Nacional Autónoma de México. 1986).

53. ANUIES - Asociación Nacional de Universidades e Instituciones de Educación Superior. (2003). México. Retrieved November 17, 2010, from: http://www.anuies.mx/e_proyectos/html/parte\%201/CUA DROS\%20DIAGNOSTICO.htm

54. Lefcourt, H. M. The construction and development of the multidimensional-Multiattributional Causality Scales. 
Research with the Locus of Control Construct. 1. (1981). 245-277.

55. Sims, J., \& Bauman, D. The tornado threat: Coping styles of the north and south. Science. 176. (1972). 1386-1392.

56. Baumann, D. D., \& Sims, J. H. Flood insurance: Some determinants of adoption. Economic Geography, 54, (1978). 189-196.

57. McClure,J.,Walkey,F.,\& Allen,M. When earthquake damage is seen as preventable: Attributions, locus of control and attitudes to risk. Applied Psychology:An International Review, 48, (1999). 239-256.

58. Spittal, M. J., McClure, J., Siegert, R. J., Walkey, F. H. Predictors of two Types of Earthquakes: Survival Activities and Mitigation Activities. Environmental and Behavior, 40, 6, (2008). 798-817.

59. Instituto Nacional para el Federalismo y el Desarrollo Municipal Gobierno del Estado de Puebla Enciclopedia de los Municipios del Estado de Puebla, 2005. (2009). Available from: http://www.elocal.gob.mx/work/templates/enciclo/puebla/Mpios/21140 a.htm [Accesed 17 November 2010].

60. Instituto Nacional para el Federalismo y el Desarrollo Municipal

Gobierno del Estado de Morelos (2005). Enciclopedia de los Municipios del Estado de Morelos. Available from: http://www.elocal.gob.mx/work/templates/enciclo/morelos /Municipios/17006a.htm [Accesed 17 November 2010].

61. López-Vázquez, E., \& Marván, M. L. Validación de una escala de afrontamiento frente a riesgos extremos. Salud Pública de México, 46, (2004). 216-221.

62. Jiménez, A.. Percepción de riesgo, estrés y afrontamiento en zonas de alto riesgo de México: Validación de instrumentos de medición. Unpublished master's thesis, Universidad de las Américas-Puebla (2002).

63. Diáz-Guerrero, R. Psicología del Mexicano: Descubrimiento de la etnopsicología. $5^{\text {th }}$ Edition. (México, Trillas. 2002).

64. Riechard, D. \& Peterson, S.J. Perception of Environmental Risk Related to Gender, Community Socioeconomic Setting, Age, and locus of control. The Journal of Environmental Education. 30 (1). (1998).

65. Corral-Verdugo, V., Frías, M. \& González, D. Percepción de riesgos, conducta proambiental y variables demográficas en una comunidad de Sonora, México. Región y Sociedad. 15. (2003). 49-72.

66. Bruchon-Schweitzer, M. (2002). Psychologie de la Santé. Modèles, concepts et méthodes. Paris: Dunod.

67. Fischhoff, B., P. Slovic, S. Lichtenstein, S. Read, \& B. Combs. (1978). How safe is safe enough? A psychometric study of attitudes towards technological risks and benefits. Policy Sciences, 9, 127-52.

68. Patiño, L.M. (2005). Comunicación de riesgo y su impacto en las poblaciones afectadas por el volcán Popocatépetl. BD Thesis. Universidad de las Américas-Puebla. 